\title{
Bioclimatic conditions of Lublin based on the Universal Thermal Climate Index (UTCI)
}

\begin{abstract}
The objective of this paper is to describe bioclimatic conditions in Lublin and Radawiec in the period 1976-2015 using the UTCl index. The paper shows that in Lublin and Radawiec, the most frequent biometeorological conditions caused no heat stress and were neutral for the human organism. At the analysed stations, biometeorological conditions causing cold stress occurred more frequently than those causing heat stress. Biometeorological conditions in the analysed period were characterised by high year-to-year variability. We observed that in recent years there was an increase in frequency of conditions favouring heat stress and a decrease in conditions favouring cold stress.
\end{abstract}

Keywords

Urban bioclimatology $\bullet$ bioclimatology $\cdot$ UTCI $\bullet$ Lublin

(C) University of Warsaw - Faculty of Geography and Regional Studies
Mateusz Dobek 조 , Sylwester Wereski $\mathbb{C}$, Agnieszka Krzyżewska (C)

Department of Hydrology and Climatology,

Faculty of Earth Sciences, University of Maria

Curie Skłodowska, Lublin, Poland

e-mail: mateusz.dobek@umcs.pl

e-mail: sylwester.wereski@umcs.pl

e-mail: agnieszka.krzyzewska@umcs.pl

Received: 3 December 2019

Accepted: 8 July 2020
Introduction

The atmospheric environment constantly affects the human organism, shaping its thermal perception, physiological processes and, in certain situations, also well-being and state of health. Components of the environment such as solar radiation, temperature, humidity, air movement, pressure, atmospheric precipitation, pollution, and ionisation of the atmosphere, as well as noise, reach the organism in the form of stimuli (Kozłowska-Szczęsna et al. 1997). Urbanised areas have specific biometeorological and bioclimatic conditions resulting from, among others, excessive human pressure and excessive transformation of the environment. In comparison to non-urbanised areas, in cities a number of elements of the atmospheric environment are subject to modifications, including changes in radiation, air temperature and humidity, wind field, noise, or air quality (e.g. Landsberg 1981; Błażejczyk 2002; Fortuniak 2003; Szymanowski 2004; Sikora 2008; Bokwa 2010; Kunert \& Błażejczyk 2011). The high number of city residents affected by modified biometeorological stimuli generates a demand for information concerning the variability of thermal perception in urbanised areas. In Poland, such studies have been conducted for, for example, Warsaw (Błażejczyk 2002; Błażejczyk et al. 2013a), Łódź (Skrzypski \& Papiernik 2006), Słubice, Zielona Góra, and Gorzów Wielkopolski (Mąkosza 2013) or Wrocław (Sikora 2008).

Research on the biometeorological and bioclimatic conditions of Lublin has been undertaken by a number of scientists. Kruczko (1962) analysed the frequency of occurrence of sultry days in the discussed area, and Zinkiewicz (1969) analysed climatic and bioclimatic conditions in economic terms. Values of Hill's cooling power in Lublin were characterised by Mrugała (1980, 1992) and Kaszewski et al. (2006). The Humidex Index was used in the description of thermal and humidity conditions in the years 1997-2006 (Dobek et al. 2008), and the Subjective Temperature Index (STI) was the basis for the comparison of the frequency of occurrence of particular thermal perceptions in Lublin and in Lesko in the period 1991-2005 (Wereski et al. 2010). Spatial variability of biometeorological conditions in Lublin was analysed by Dobek et al. (2013) and Dobek (2015). The UTCI index was applied in combination with atmospheric circulation in bioclimatic research concerning the discussed city by Bartoszek et al. (2017). Dobek and Krzyżewska (2015) explored the bioclimatic conditions of Lublin by analysing frequencies of occurrence of particular UTCI classes in the years 1952-2015. No studies are currently available analysing long-term bioclimatic conditions in the centre of the city and its peripheries. The objective of the paper is to characterise general bioclimatic conditions in Lublin and in its peripheries in a multi-annual period using the UTCI index.

\section{Study Area}

Lublin is the largest city east of the Vistula River in Poland. Its surface area is $147 \mathrm{~km}^{2}$. It has a population of approximately 340,000 (Statistical Office in Lublin 2019). It is an academic centre with five main state universities and several smaller private ones. Students represent about $20 \%$ of population, and most are not Lublin residents. There are many tourists who come to visit some of the famous historical places (Old Town, castle, Open Air Village Museum, State Muzeum at Majdanek, The Nazi German Concentration and Extermination Camp) and international festivals (Carnaval Sztukmistrzów, Theatre Confrontations Festival, European Festival of Taste, and more). Based on the 


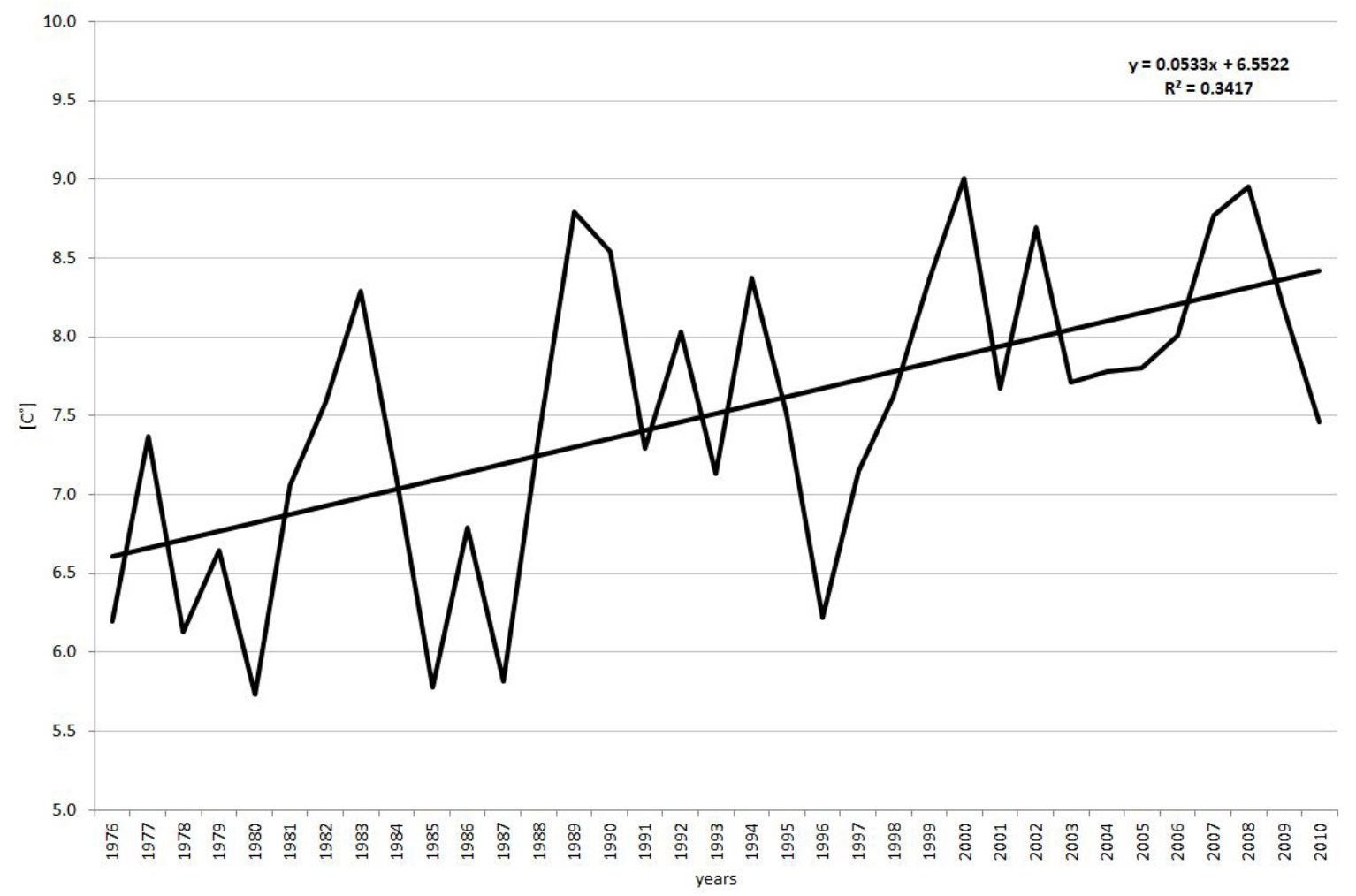

Figure 1. The average annual air temperature [ ${ }^{\circ} \mathrm{C}$ ] in Radawiec in 1976-2010 Source: author's elaboration

meteorological data from Lublin Radawiec (hereafter referred to as "Radawiec"), the average multi-annual air temperature in the years $1976-2010$ was $7.5^{\circ} \mathrm{C}$. The lowest average annual air temperature occurred in 1980 and was $5.7^{\circ} \mathrm{C}$. The highest average annual air temperature was recorded as $9.0^{\circ} \mathrm{C}$, in the year 2000 (Fig. 1). In the period 1976-2010 there was an increase in the average annual air temperature with a statistically significant trend $(\alpha=0.05)$.

In the annual course, the warmest month in Radawiec was July $\left(17.9^{\circ} \mathrm{C}\right)$ and the coldest was January $\left(-3.1^{\circ} \mathrm{C}\right)$. The mean monthly air temperature showed great variability from year to year, from $-13.7^{\circ} \mathrm{C}$ to $2.2^{\circ} \mathrm{C}$ in January of 1987 and 2007 , respectively, and from $14.3^{\circ} \mathrm{C}$ to $21.5^{\circ} \mathrm{C}$ in July of 1979 and 2006, respectively. The absolute minimum air temperature was $-33.7{ }^{\circ} \mathrm{C}$ and occurred on January 8,1987 . The absolute maximum temperature of $35.3^{\circ} \mathrm{C}$ was recorded on August 29, 1992. The lowest mean daily air temperature of $-25.6{ }^{\circ} \mathrm{C}$ occurred on January 8,1987 . The highest average daily air temperature was recorded on August 29, 1992 and was $27.1^{\circ} \mathrm{C}$.

Lublin, as well as most of the Polish territory is, according to the Köppen climate division, in a Cfb zone (warm temperature, fully humid, warm summer [Kottek et al. 2006]). In the bioclimatic regionalisation of Poland by Kozłowska-Szczęsna (1997), Lublin is located in region $\mathrm{V}$ - South-Eastern. The area is characterised by a high number of onerous days related to heat stress (KozłowskaSzczęsna et al. 1997). This regionalisation was based on Hill's cooling ( $\mathrm{H}$-cooling) power: days with heat discomfort were defined as days with a below $210 \mathrm{~W} / \mathrm{m}^{2}$. The described regionalisation was modified by Błażejczyk (2004), who also included this area in region $\mathrm{V}$ - South-Eastern. Based on the analysis of the frequency of weather types, subtypes and classes, the area is characterised by higher frequency of onerous biothermal conditions in comparison to other regions of Poland, with a high share of very hot weather, and more days with strong sultriness.

During an extreme mega-heatwave event in August 2015, Lublin and the whole South-Eastern (V) bioclimatic region, was exposed to more days with strong heat stress (SHS) and very strong heat stress (VSHS) than other parts of the country (with the only exception of the Central region, IV). During this heatwave in Lublin-Radawiec there were 87 SHS+VSHS cases from 24 hourly observations, which was the maximum in this region. In Poland the maximum was recorded in Opole (104 cases, Central region, IV) (Krzyżewska et al. 2020).

Based on the seasonal UTCI average (1971-90), the lowest heat load at 12.00 UTC in summer (JJA) occurs in the Coastal and South-Eastern regions (the UTCI value does not exceed $\left.19{ }^{\circ} \mathrm{C}\right)$. In the winter season (DJF), the South-Eastern region is one of the coldest along with the North-Eastern and Upland (UTCI value below $-8.0^{\circ} \mathrm{C}$ ) (Błażejczyk \& Kunert 2011).

In this paper we used meteorological data from the weather station of the Institute of Meteorology and Water Management (IMGW PIB) in Lublin-Radawiec and Meteorological Observatory of the Department of Hydrology and Climatology of UMCS in Litewski Square (hereafter referred to as "Lublin") (Fig. 2). Radawiec is located to the south-west of Lublin, at approximately $12 \mathrm{~km}$ from the city centre $\left(\varphi=51^{\circ} 13^{\prime} \mathrm{N}\right.$, $\lambda=22^{\circ} 24^{\prime} \mathrm{E}$ ), with an elevation of $238 \mathrm{~m}$ a.s.l. This station represents meteorological conditions of non-urbanised areas. The UMCS station in the Litewski Square is located in the city centre, in a square with a high share of greenery, particularly tall vegetation (Fig. 3$)\left(\varphi=51^{\circ} 14^{\prime} 55.09^{\prime \prime} \mathrm{N}, \lambda=22^{\circ} 33^{\prime} 37.63^{\prime \prime} \mathrm{E}\right.$, elevation 194 m a.s.I.).

\section{Material and Methods}

The meteorological data are from the period 1976-2015, recorded at 12 UTC, which in bioclimatology is considered as 


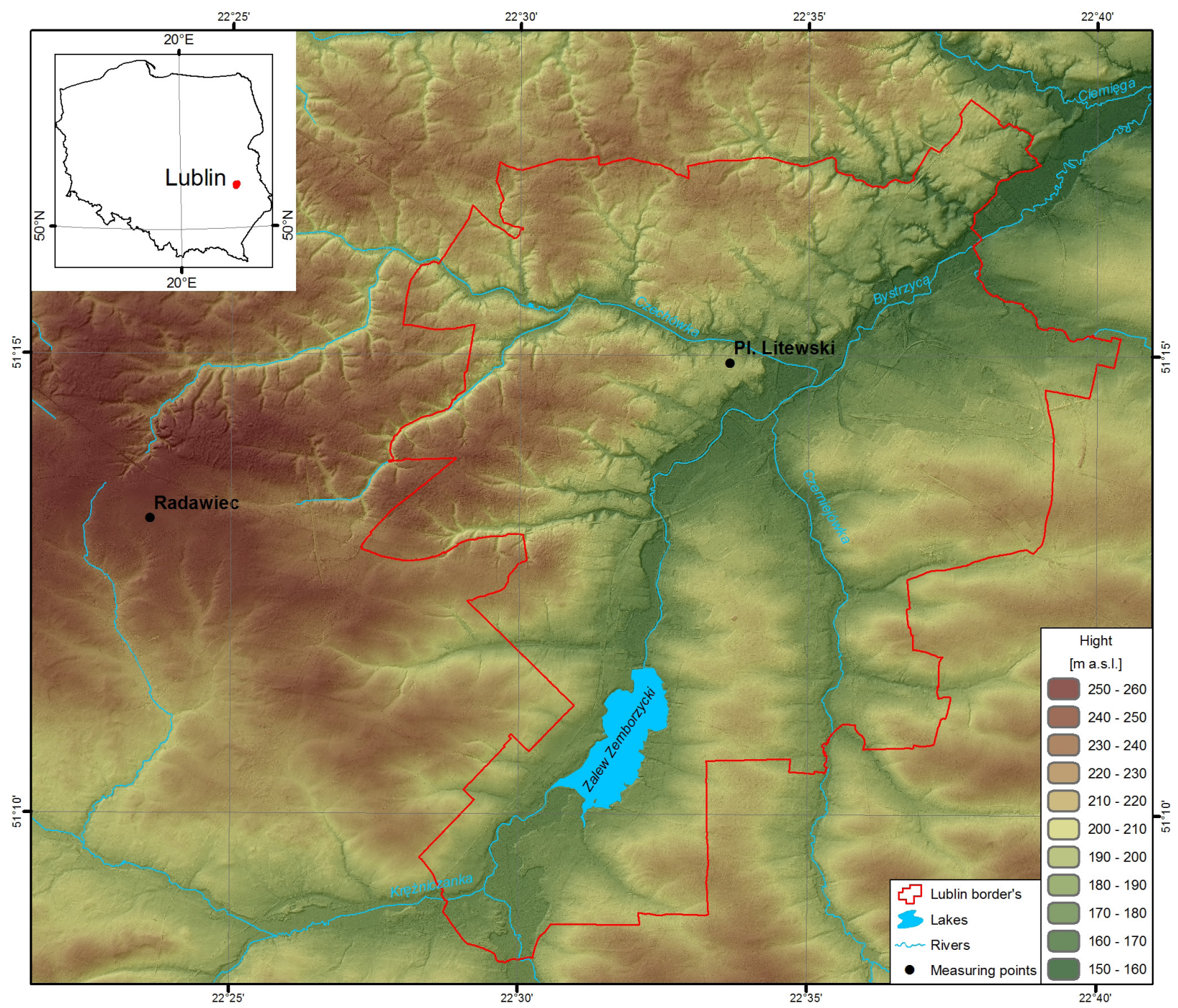

Figure 2. Location of measurement points Source: author's elaboration

representative of the time of day with the most intensive human activity (Kozłowska-Szczęsna et al. 1997). The data include: air temperature, relative air humidity, wind speed and cloudiness.

In the paper, bioclimatic conditions were determined by the Universal Thermal Climate Index (UTCI). It is based on an extended human heat balance model, the so-called Fiala Model (Fiala et al. 2001; Fiala et al. 2012), which includes two parameters of regulation of heat exchange between the human organism and the surroundings. The first, referred to as as "passive", covers heat transport within the organism and on the body surface. The second, called "active", determines physiological thermoregulation mechanisms. UTCl values expressed in ${ }^{\circ} \mathrm{C}$ are obtained based on multiple calculation of the human heat balance. This way, further parameters are obtained that are necessary to obtain the final result. The UTCI index can be expressed as the following function:

$\mathrm{UTCl}=\mathrm{f}(\mathrm{Ta}, \mathrm{vp}, \mathrm{va}, \mathrm{dTmrt})$

where: Ta - air temperature $\left[{ }^{\circ} \mathrm{C}\right]$, vp - water vapour pressure $[\mathrm{hPa}]$, va - wind speed at a height of $10 \mathrm{~m}$ above ground level $\left[\mathrm{m} \cdot \mathrm{s}^{-1}\right], \mathrm{dTmrt}$ - difference between mean radiation temperature and air temperature $\left[{ }^{\circ} \mathrm{C}\right]$.

Tmrt (mean radiation temperature) reflects the temperature of the thin layer of air surrounding the human body. The value is determined by short- and long-wave radiation fluxes reaching the human body.

Details on the construction of the index, a description of all its components, and verification are included in papers by, among others, Błażejczyk et al. (2012), Bröde et al. (2012), Fiala et al. (2012), Haventih et al. (2012), Kampmann et al. (2012) and Psikuta et al. (2012). UTCI values were calculated on BioKlima 2.6 computer software by Błażejczyk and Błażejczyk (IGiPZ PAN 2019). Table 1 presents classes of thermal stress of the human organism according to the UTCI index. The statistical significance of trends was analysed by Mann-Kendall test (Salmi et al. 2002).

\section{Results}

In the analysed period, mean air temperature at 12.00 UTC in Lublin was $11.1^{\circ} \mathrm{C}$, and in Radawiec it was considerably lower, with a value of $10.6^{\circ} \mathrm{C}$ (Table 2). The lowest mean annual air temperature in this term in Lublin occurred in $1979\left(8.8^{\circ} \mathrm{C}\right)$, and in 


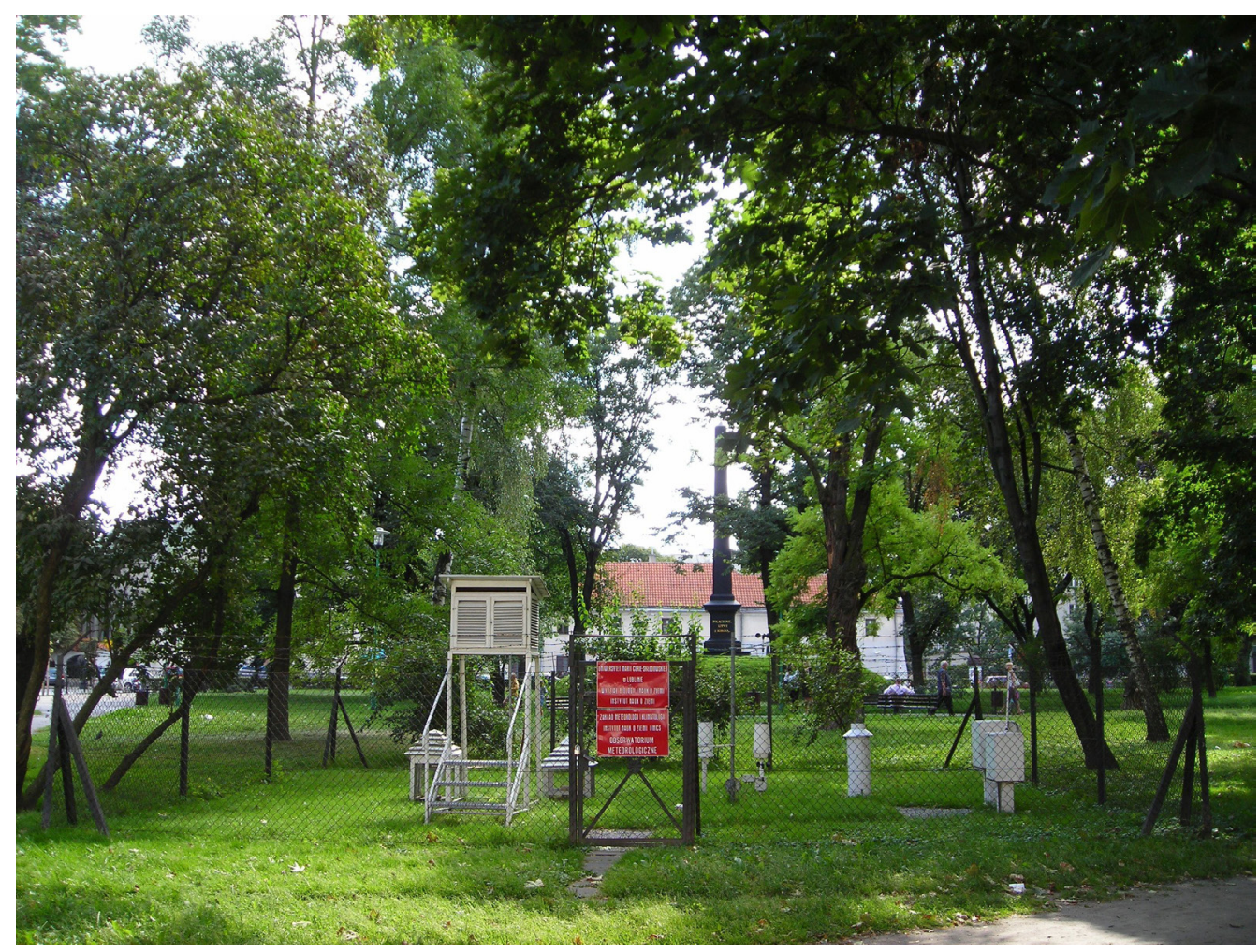

Figure 3. Surroundings of the UMCS meteorological station in Lublin Source: photo taken by Sylwester Wereski

Table 1. Scale of assessment of thermal stress of the organism according to the UTCI index

\begin{tabular}{|c|c|c|}
\hline $\begin{array}{l}\text { UTCl } \\
{\left[{ }^{\circ} \mathrm{C}\right]}\end{array}$ & Thermal stress & Prevention \\
\hline$>+46$ & Extreme heat stress (EHS) & $\begin{array}{l}\text { Necessary periodical cooling of the organism, necessary supplementation of liquids > } \\
\qquad 0.5 \mathrm{l} / \mathrm{h} \text {; avoid intensive physical activity. }\end{array}$ \\
\hline $\begin{array}{l}+38- \\
+46\end{array}$ & $\begin{array}{l}\text { Very strong heat stress } \\
\text { (VSHS) }\end{array}$ & $\begin{array}{l}\text { Necessary periodical use of air-conditioned rooms or shaded areas; necessary } \\
\text { supplementation of liquids }>0.5 \mathrm{l} / \mathrm{h} \text {; limit physical activity }\end{array}$ \\
\hline $\begin{array}{l}+32- \\
+38\end{array}$ & Strong heat stress (SHS) & $\begin{array}{c}\text { Necessary supplementation of liquids } 0.25 \mathrm{l} / \mathrm{h} \text {; recommended use of shaded areas, and } \\
\text { periodical limiting of physical activity }\end{array}$ \\
\hline $\begin{array}{l}+26- \\
+32\end{array}$ & Moderate heat stress (MHS) & Necessary supplementation of liquids $0.25 \mathrm{I} / \mathrm{h}$ \\
\hline $\begin{array}{l}+9- \\
+26\end{array}$ & Thermoneutral zone (TZ) & Physiological thermoregulation processes are sufficient to maintain thermal comfort \\
\hline $0-+9$ & Slight cold stress (SICS) & Recommended use of gloves and a hat \\
\hline$-13-0$ & Moderate cold stress (MCS) & Intensify physical activity and protect extremities and face from cold \\
\hline $\begin{array}{l}-27- \\
-13\end{array}$ & Strong cold stress (SCS) & $\begin{array}{l}\text { Intensify physical activity and protect extremities and face from cold; recommended } \\
\text { increase in the thermo-isolation properties of clothing }\end{array}$ \\
\hline $\begin{array}{l}-40- \\
-27\end{array}$ & $\begin{array}{l}\text { Very strong cold stress } \\
\text { (VSCS) }\end{array}$ & $\begin{array}{c}\text { Intensify physical activity and protect extremities and face from cold; necessary increase } \\
\text { in the thermo-isolation properties of clothing, and limited time spent outdoors }\end{array}$ \\
\hline$<-40$ & Extreme cold stress (ECS) & $\begin{array}{l}\text { Limit time spent outdoors to the necessary minimum; necessary increase in the thermo- } \\
\text { isolation and wind-proof properties of clothing }\end{array}$ \\
\hline
\end{tabular}

Source: Błażejczyk et al. 2013 
MISCELLANEA GEOGRAPHICA - REGIONAL STUDIES ON DEVELOPMENT

Vol. $24 \cdot$ No. $3 \cdot 2020 \cdot$ pp. 118-127 • ISSN: 2084-6118 • DOI: 10.2478/mgrsd-2020-0025

Table 2. Mean monthly air temperature values at 12 UTC in Lublin and Radawiec (1976-2015)

\begin{tabular}{|c|c|c|c|c|c|c|c|c|c|c|c|c|c|}
\hline $\begin{array}{c}\text { Name of } \\
\text { station }\end{array}$ & I & II & III & IV & V & VI & VII & VIII & IX & X & XI & XII & Annual mean \\
\hline Lublin & -1.2 & 0.2 & 5.2 & 12.0 & 17.8 & 20.5 & 22.5 & 22.3 & 17.1 & 11.7 & 5.1 & 0.5 & 11.1 \\
\hline Radawiec & -1.7 & -0.4 & 4.7 & 11.4 & 17.1 & 19.8 & 21.9 & 21.8 & 16.7 & 11.3 & 4.6 & -0.2 & 10.6 \\
\hline
\end{tabular}

14
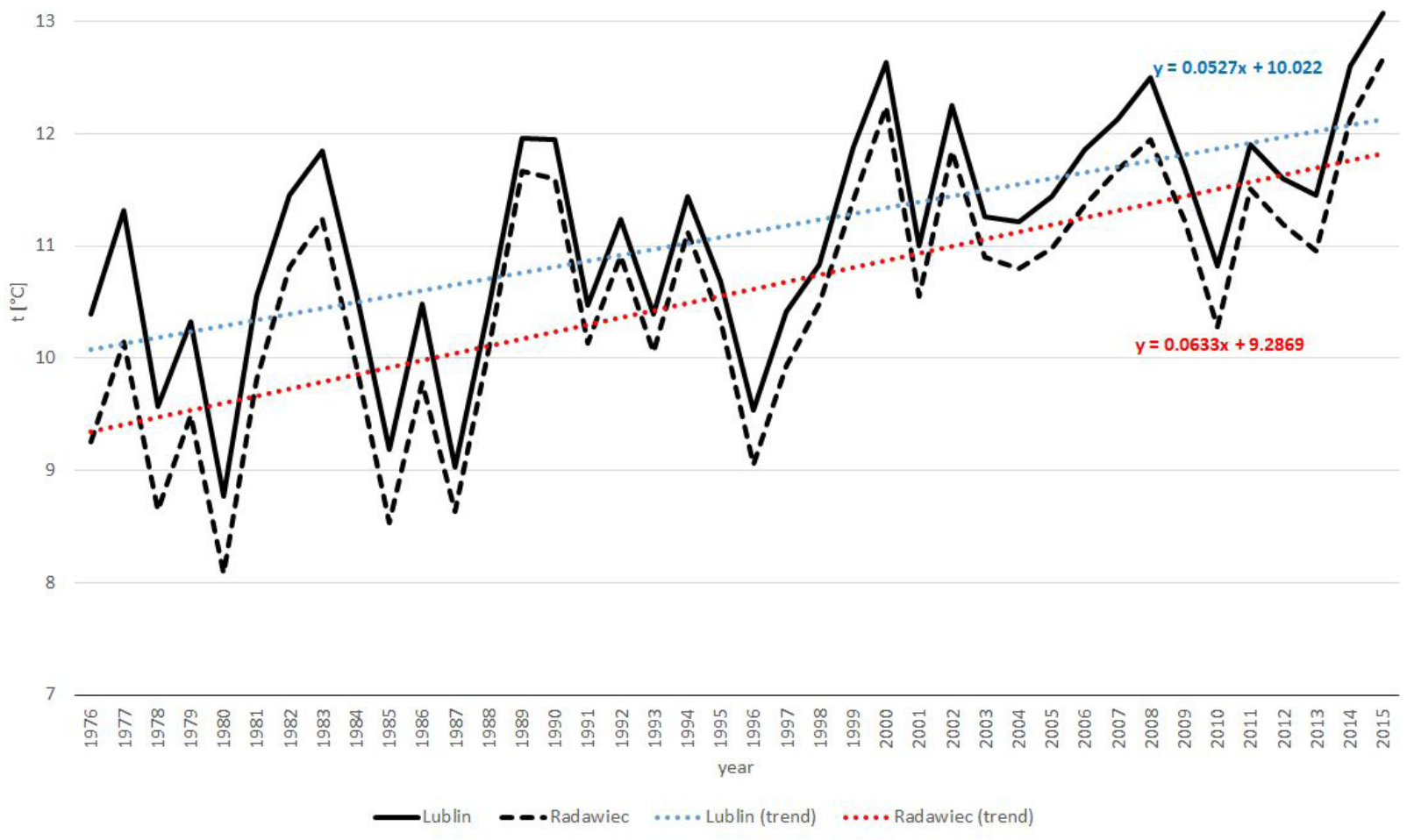

Figure 4. Course of mean annual air temperature values (in ${ }^{\circ} \mathrm{C}$ ) at 12 UTC in Lublin and Radawiec (1976-2015) Source: author's elaboration

Radawiec in $1980\left(8.1^{\circ} \mathrm{C}\right)$. The highest mean annual air temperature was recorded in 2015 , reaching $13.1^{\circ} \mathrm{C}$ in Lublin, and $12.7^{\circ} \mathrm{C}$ in Radawiec (Fig. 4). At both stations in the analysed period, a statistically significant increasing air temperature trend is observed.

In the annual course, at 12 UTC, the coldest month in Lublin and Radawiec was January, with mean air temperatures of $-1.2^{\circ} \mathrm{C}$ and $-1.7^{\circ} \mathrm{C}$, respectively. The warmest month was July, with mean air temperatures of $22.5^{\circ} \mathrm{C}$ in the city and $21.9^{\circ} \mathrm{C}$ outside the city. The complex effect of the atmospheric environment on the human organism is reflected by the UTCI bioclimatic index. In the period 1976-2015, statistically significant increasing tendencies (trend significant at a level of 0.001) occurred in the annual course of the index values (Fig. 5). An increase in annual mean values of UTCI in the $21^{\text {st }}$ century and a decrease in changes from year to year are also observed.

Year-to-year variability in the discussed multi-annual period is observed (Fig. 6). In some years (e.g. 1976, 1985, 1987, 1996, 2014), at both analysed stations, at 12 UTC, a slightly higher share of classes related to cold stress was recorded (Strong cold stress [SCS], very strong cold stress [VSCS]). Although it did not occur in all years, the very strong cold stress class [VSCS] occurred more frequently in the $20^{\text {th }}$ century. An increase in the frequency of heat stress has occurred since the 1990s, particularly the strong heat stress [SHS] and very strong heat stress [VSHS] classes. A total of 21 cases of very strong heat stress [VSHS] and one of extreme heat stress [EHS] occurred in the city. Outside the city, no conditions related to extreme heat stress [EHS], and a lower number of cases of very strong heat stress [VSHS] than in Lublin, were recorded (10).

In the analysed years, there was an increase in the number of days with no heat load (TZ) by 2 days in Lublin and 11 in Radawiec (Fig. 7). Biometeorological conditions connected with the occurrence of heat stress, i.e. strong heat stress [SHS], very strong heat stress [VSHS] and extreme heat stress [EHS], increased over the last 10 years by an average of 10 days in the city and outside the city.

At both stations there was a decrease in the number of days causing body cooling (Strong cold stress [SCS], very strong cold 


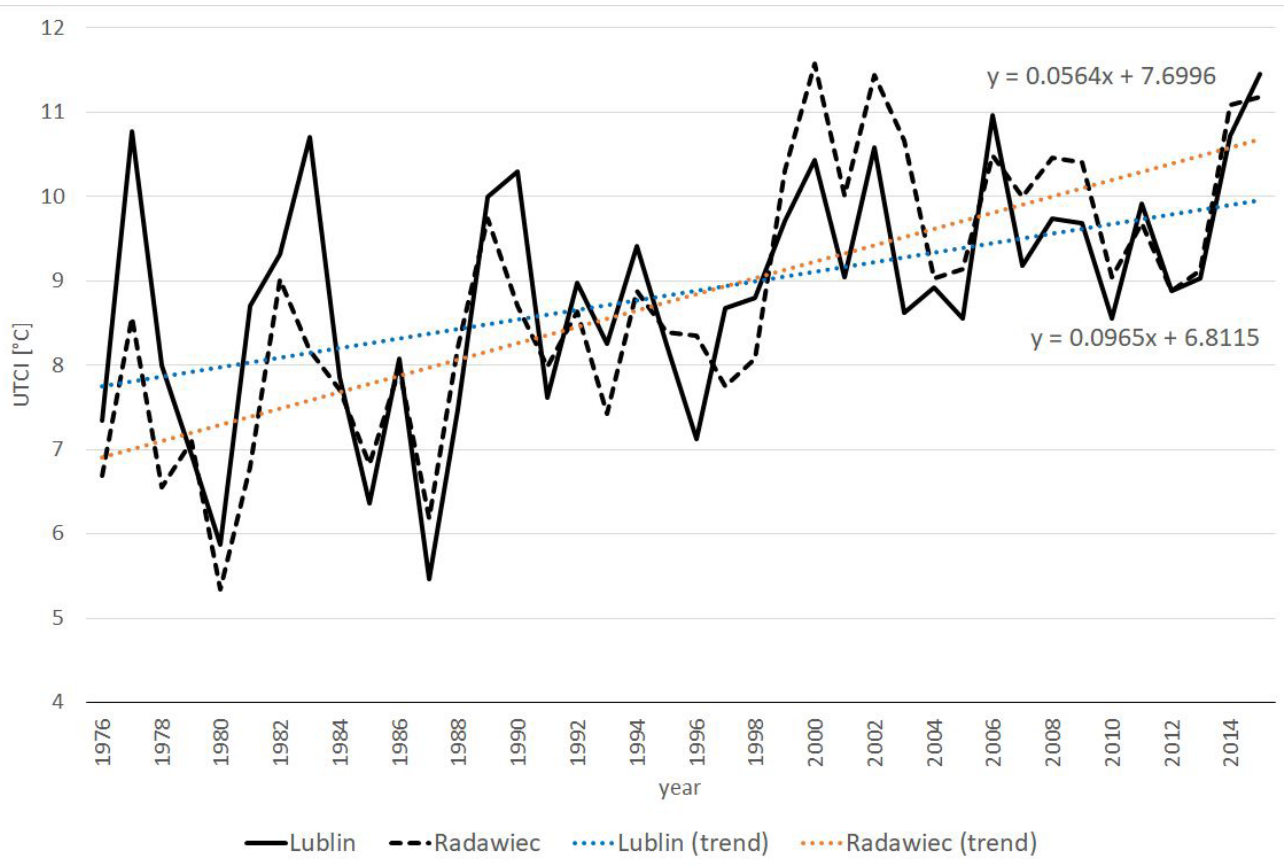

Figure 5. Course of mean annual values of the UTCI index at 12 UTC in Lublin and Radawiec (1976-2015) Source: author's elaboration

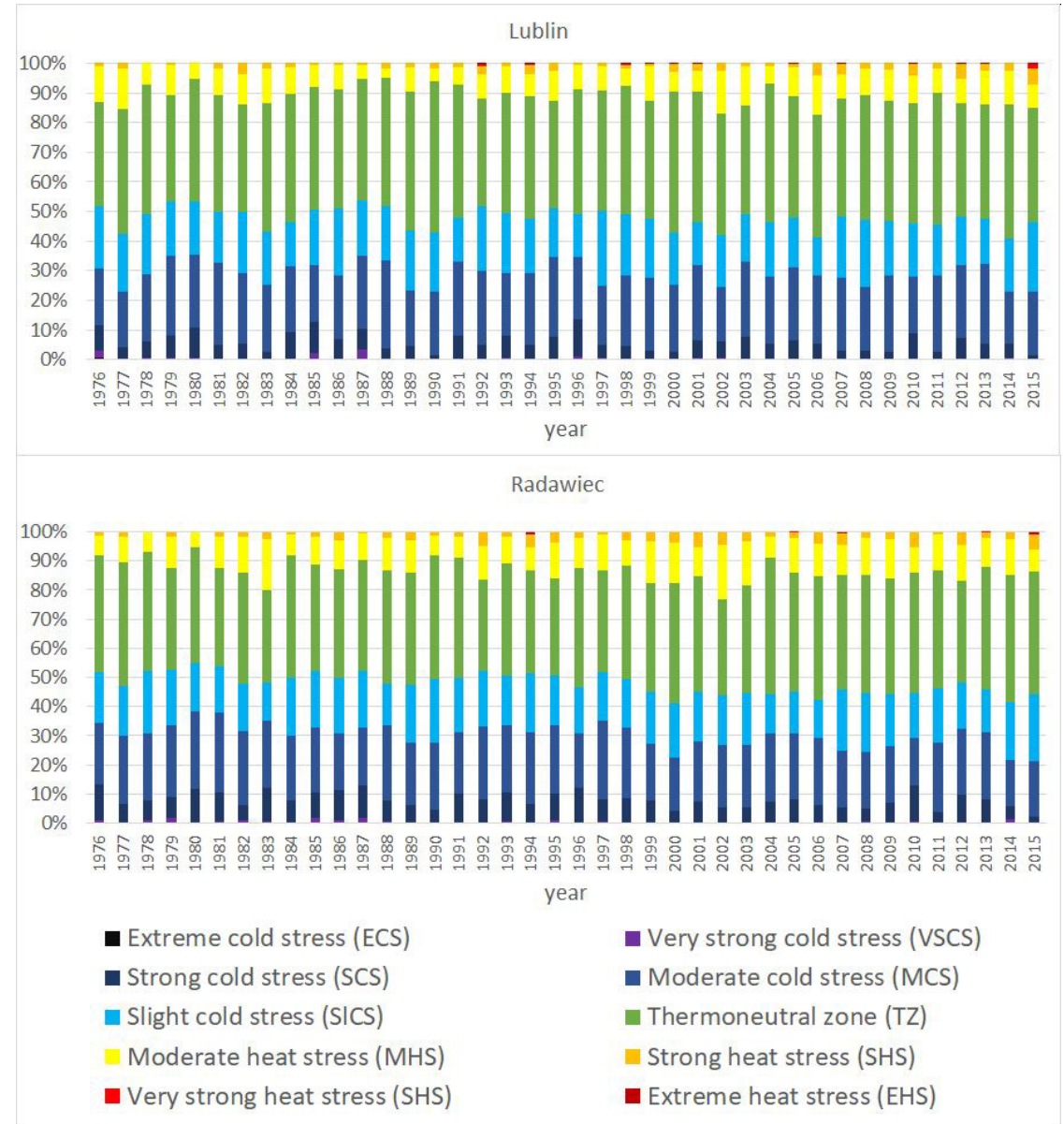

Figure 6. Long-term course of frequency of occurrence of UTCI heat load in Lublin and Radawiec in the period 1974-2015 Source: author's elaboration 
MISCELLANEA GEOGRAPHICA - REGIONAL STUDIES ON DEVELOPMENT

Vol. $24 \cdot$ No. $3 \cdot 2020 \cdot$ pp. 118-127 • ISSN: 2084-6118 • DOI: 10.2478/mgrsd-2020-0025

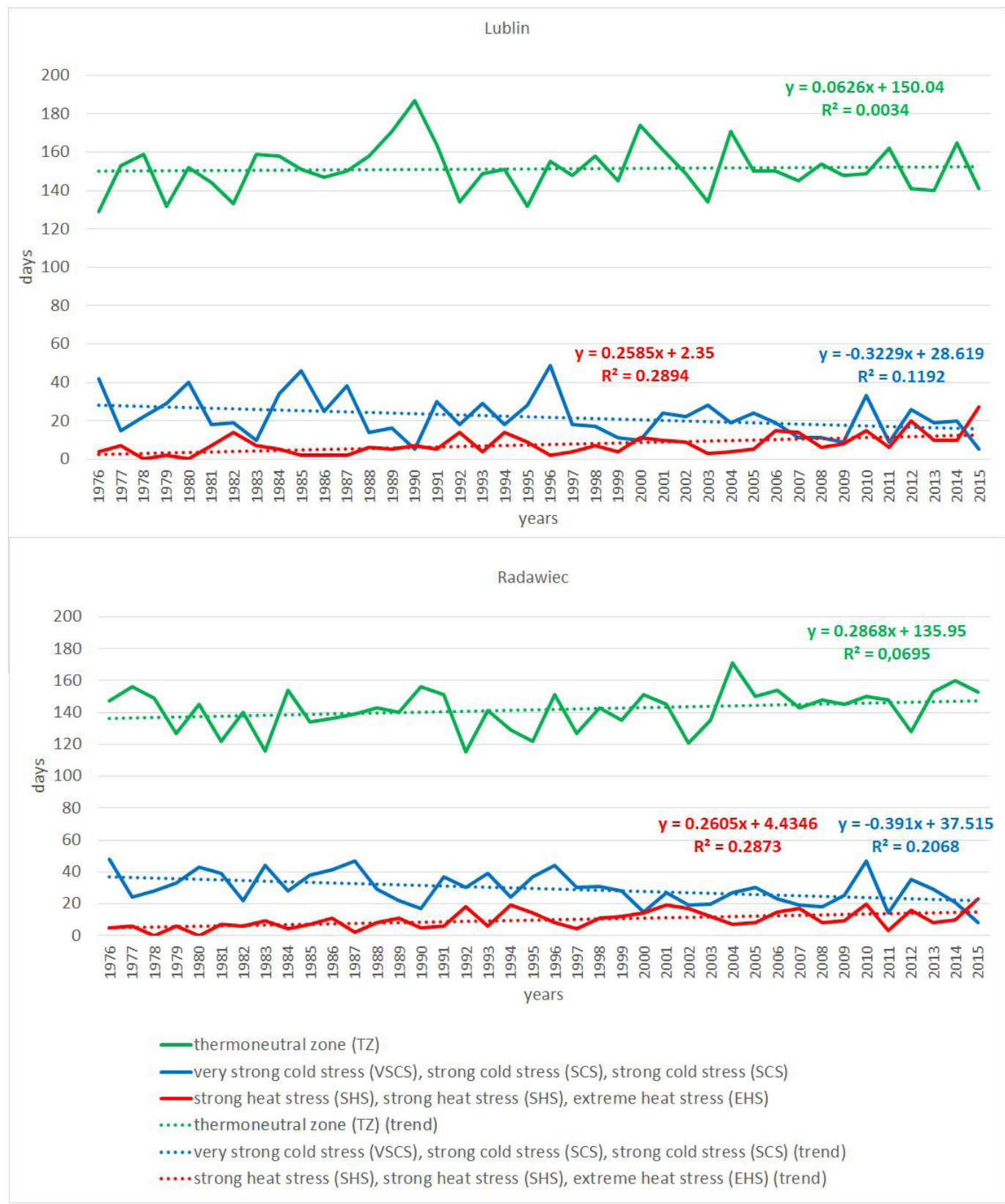

Figure 7. The course of average annual values of selected thermal loads of the UTCI at 12 UTC in Lublin and Radawiec (1976-2015) Source: author's study

stress [VSCS], extreme cold stress [ECS]). In the case of Lublin, it was on average 12 days, and in Radawiec 15 days. These trends show the insignificant impact of the city on alleviating atmospheric conditions that burden the human body.

In the discussed multi-annual period in Lublin and Radawiec, thermoneutral zone [TZ] occurred the most frequently $(41.6 \%$ and $38.8 \%$, respectively) (Table 3 ). As shown by Dobek and Krzyżewska (2015) during 1952-2010 the thermoneutral zone class [TZ] was observed for $39 \%$ of days of the year. These biometeorological situations favourable to the functioning of the human organism occurred primarily from March to September. In Lublin they occurred throughout the year, and outside the city no such conditions were recorded in January (Fig. 8). Atmospheric conditions causing cold stress of the organism at
12 UTC occurred on approximately $50 \%$ of all the discussed days in Lublin (47.8\%) and in Radawiec (47.9\%). In this group, the moderate cold stress class [MCS] occurred the most frequently. It occurred earliest in the spring and autumn periods, and more often in Radawiec than in the city. In Lublin, biometeorological conditions causing the strongest cold stress, i.e. extreme cold stress [ECS], were recorded four times. Interestingly, at 12 UTC, such situations outside the city occurred more seldom, i.e. only twice.

Biometeorological conditions characterised as thermal stress categories potentially causing heat stress accounted for $11.0 \%$ of all cases in the city, and $13.3 \%$ outside the city. Out of this group, moderate heat stress [MHS] occurred the most frequently (8.7\% in Lublin and $10.6 \%$ in Radawiec), particularly 
Table 3. Annual occurrence of particular UTCl classes (in \%) in Lublin and Radawiec in the period 1974-2015

\begin{tabular}{|c|c|c|c|c|c|c|c|c|c|c|}
\hline Station & $\begin{array}{c}\text { Extreme } \\
\text { cold } \\
\text { stress } \\
\text { (ECS) }\end{array}$ & $\begin{array}{c}\text { Very } \\
\text { strong } \\
\text { cold } \\
\text { stress } \\
\text { (VSCS) }\end{array}$ & $\begin{array}{c}\text { Strong } \\
\text { cold } \\
\text { stress } \\
\text { (SCS) }\end{array}$ & $\begin{array}{c}\text { Moderate } \\
\text { cold } \\
\text { stress } \\
\text { (MCS) }\end{array}$ & $\begin{array}{c}\text { Slight } \\
\text { cold } \\
\text { stress } \\
\text { (SICS) }\end{array}$ & $\begin{array}{c}\text { Thermoneutral } \\
\text { zone (TZ) }\end{array}$ & $\begin{array}{c}\text { Moderate } \\
\text { heat } \\
\text { stress } \\
\text { (MHS) }\end{array}$ & $\begin{array}{c}\text { Strong } \\
\text { heat } \\
\text { stress } \\
\text { (SHS) }\end{array}$ & $\begin{array}{c}\text { Strong } \\
\text { heat } \\
\text { stress } \\
\text { (SHS) }\end{array}$ & $\begin{array}{c}\text { Extreme } \\
\text { heat } \\
\text { stress } \\
\text { (EHS) }\end{array}$ \\
\hline Lublin & 0 & 0.4 & 5.6 & 23.1 & 18.4 & 41.6 & 8.7 & 2 & 0.2 & 0 \\
\hline Radawiec & 0 & 0.5 & 7.6 & 22.1 & 17.7 & 38.8 & 10.6 & 2.6 & 0.1 & - \\
\hline
\end{tabular}
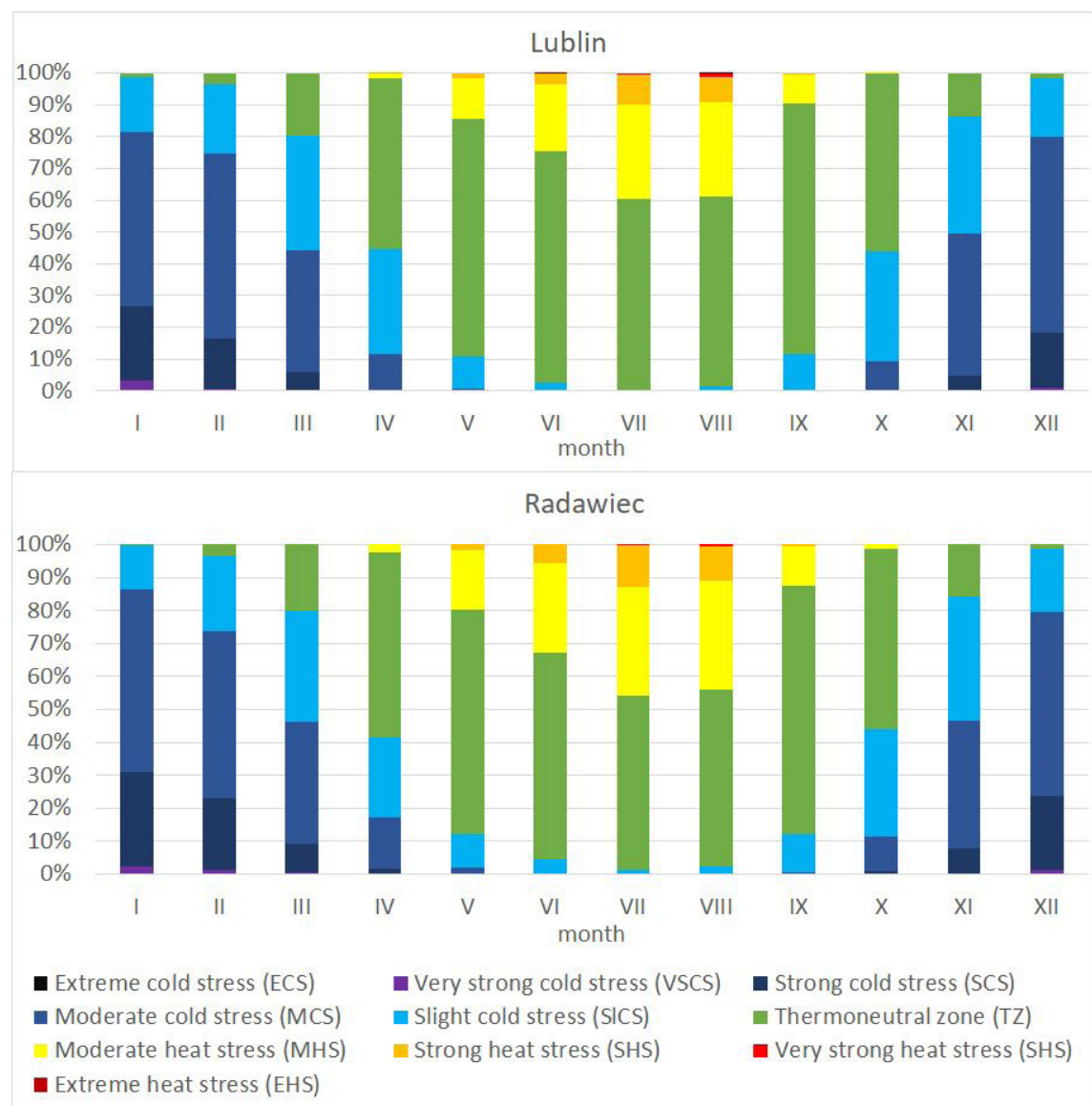

Figure 8. Annual course of frequency of occurrence of particular UTCl classes in Lublin and Radawiec in the period 1974-2015 Source: author's elaboration

from May to September, and usually in July and August. It is worth mentioning that, outside the city, meteorological situations with a risk of causing heat stress (strong heat stress [SHS]) were recorded slightly more frequently. This can be explained by the fact that the meteorological station in Lublin is surrounded by trees that may mitigate the effects causing heat stress. In Lublin, biometeorological conditions causing the strongest heat stress, i.e. extreme heat stress [EHS], occurred once at 12 UTC (on 29.08.1992).

\section{Summary}

The objective of this paper was to describe bioclimatic conditions in Lublin and Radawiec in the period 1976-2015 using the UTCl index. The paper showed that in Lublin and Radawiec, the most frequent biometeorological conditions caused no heat stress and were neutral for the human organism. Similar results, with the highest frequency of no heat stress, were presented by Kuchcik (2017), who analysed 12 meteorological stations from Poland for $1975-2014$. In the city it was on average $42 \%$ of days in a year, and outside the city $39 \%$.

At the analysed stations, biometeorological conditions causing cold stress occurred more frequently than those causing heat stress. Heat stress occurred more seldom in the vicinity of the meteorological station in the city than outside the city. This can be explained by the fact that situations causing heat stress of the human organism in urban areas were mitigated by vegetation growing in Litewski Square. This confirms the positive role of greenery in cities in terms of the health and comfort of residents, especially during heat waves (Oliviera et al. 2011, $\mathrm{Ng}$ et al. 2012). Similar findings were presented for the Warsaw agglomeration, 
where high values of UTCI were observed in street canyons in the city centre and in the city outskirts, and lower values occurred on city squares covered by trees (Błażejczyk et al. 2014). The influence of municipal greenery in lowering air temperature (especially during the growing season) and so in lowering heat load, was described by Spronken-Smith and Oke (1998) and Makhelouf (2009).

Biometeorological conditions in the period 1976-2015 were characterised by high year-to-year variability. An increase in the frequency of conditions favouring the occurrence of heat stress 'at the cost' of conditions favouring cold stress has been observed in recent years, which is in accordance with research from other cities (e.g., Sikora 2008; Błażejczyk et al. 2013a; Dobek et al. 2013; Mąkosza 2013; Tomczyk \& Owczarek 2020). Błażejczyk et al. (2015) forecast that in the $21^{\text {st }}$ century the average UTCI value (at 12 UTC) will systematically increase. Depending on the adopted scenarios for climate change, at the end of the $21^{\text {st }}$ century SRES will be from 8.8 to $10.6^{\circ} \mathrm{C}\left(6.5^{\circ} \mathrm{C}\right.$ in the reference period 1990 2000). In Lubelskie Voivodeship, the average UTCI value is forecast to fall by $2-4{ }^{\circ} \mathrm{C}$ (Błażejczyk et al. 2015). Further changes in the number of days with strong cold stress (a decrease from $10 \%$ in the reference period to $6.0-7.7 \%$ by the end of the century) and with strong heat stress (an increase from $2 \%$ in the reference period to $5-15 \%$ ) will also be observed at the end of the century. In the Lublin region these changes will be: from -3 to $-6 \%$ of days with strong cold stress and from +4 to $+17 \%$ of days with strong heat stress.

\section{References}

Bartoszek, K, Wereski, S, Krzyżewska, A \& Dobek, M 2017, 'The influence of atmospheric circulation on bioclimatic conditions in Lublin (Poland)', Bulletin of Geography, Physical Geography Series, vol. 12, pp. 41-49.

Błażejczyk, K 2002, Importance of circulation and local conditions in shaping the climate and bioclimate of the Warsaw agglomeration', Dokumentacja Geograficzna, vol. 26, pp. 162.

Błażejczyk, K 2004, 'Bioklimatyczne uwarunkowania turystyki i rekreacji w Polsce' ['Bioclimatic conditions of tourism and recreation in Poland'], Prace Geograficzne, vol. 192, pp. 291.

Błażejczyk, K, Epstein, Y, Jendritzky, G, Staiger H \& Tinz, B 2012, 'Comparison of UTCI to selected thermal indices', International Journal of Biometeorology, vol. 56(3), pp. $515-535$.

Błażejczyk, K \& Kunert, A 2011, 'Bioclimatic principles of recreation and tourism in Poland' Monographies, vol. 13, IGiPZ PAN, Warsaw, pp. 368.

Błażejczyk, K, Kuchcik, M, Milewski, P, Dudek, W, Kręcisz, B, Błażejczyk, A, Szmyd, J, Degórska, B \& Pałczyński, C 2014, 'Miejska wyspa ciepła w Warszawie' ['Urban heat island in Warsaw], Wydawnictwo Akademickie SEDNO, IGiPZ PAN, Warsaw.

Błażejczyk, K, Baranowski, J \& Błażejczyk, A 2015, 'Influence of climate on health status in Poland and projection to the year 2100' Wydawnictwo Akademickie SEDNO, IGiPZ PAN, Warsaw.

Błażejczyk, K, Idzikowska, D \& Błażejczyk A 2013a, 'Forecast changes for heat and cold stress in Warsaw in the 21st century, and their possible influence on mortality risk', Papers on global change, vol. 20, pp. 47-62.

Błażejczyk, K, Jendritzky, G, Bröde, P, Fiala, D, Havenith, G, Epstein, Y, Psikuta, A \& Kampmann, B 2013b, 'An introduction to the Universal Thermal Climate Index (UTCI)', Geographia Polonica, vol 86(1), pp. 5-10.

Bokwa, A 2010, 'Wieloletnie zmiany struktury mezoklimatu miasta na przykładzie Krakowa' ['Multi-annual changes in the
The described changes can have negative impacts on the health of residents, especially the elderly, who have impaired mechanisms of body thermoregulation (Kovats \& Hajat 2008). Unfortunately, most apartments do not have air conditioning, which can increase the number of deaths (O'Neil et al. 2009) during heatwaves similar to the 2015 event. Also, tourism can be negatively affected by increases in number of days with heat stress - especially urban tourism (Scott \& Lemieux 2010). Lublin is popular tourist destination, especially in the warm part of the year, when most of the cultural events take place.

The obtained results can be a valuable guideline for the city's residents concerning the most frequent bioclimatic conditions in particular periods in a year. Also, foreign visitors, like tourists or students, can use the knowledge when planning a visit in Lublin and its vicinity.

\section{ORCID}

Mateusz Dobek (D) https://orcid.org/0000-0001-5614-436X

Sylwester Wereski (D) https://orcid.org/0000-0003-4726-0363

Agnieszka Krzyżewska (1) https://orcid.org/0000-0002-4358-059X structure of the mesoclimate of a city based on the example of Cracow'], Instytut Geografii I Gospodarki Przestrzennej UJ, Kraków.

Bröde, P, Fiala, D, Błażejczyk, K, Holmér, I, Jendritzky, G, Kampmann, B, Tinz, B \& Havenith, G 2012, 'Deriving the operational procedure for the Universal Thermal Climate Index (UTCI)', International Journal of Biometeorology, vol. 56(3), pp. 481-494.

Dobek, M 2015, 'Zróżnicowanie temperatury ekwiwalentnej w Lublinie w latach 2009-2010' ['Variability of equivalent temperature in Lublin in the years 2009-2010'], Annales UMCS sec.B, vol. 68(2), pp. 79-90.

Dobek, M, Demczuk, P \& Nowosad, M 2013, 'Spatial variation of the Universal Thermal Climate Index in Lublin in specified weather scenarios', Annales UMCS sec.B, vol. 68, pp. 2138.

Dobek, M, Krzyżewska, A 2015, 'Wybrane zagadnienia z bioklimatu Lublina' ['Selected issues concerning the bioclimate of Lublin'], Annales UMCS, sec. B, vol. 70(2), pp. 117-129.

Dobek, M, Siłuch, M, Wereski, S, Bartoszek, K \& Skiba, K 2008, 'Czas trwania i częstość występowania uciążliwych warunków bioklimatycznych w Lublinie na podstawie wskaźnika Humidex' ['Duration and frequency of occurrence of onerous bioclimatic conditions in Lublin based on the Humidex index'] in Klimat i bioklimat miast, eds. K Kłysik, J Wibig, \& K Fortuniak, Wydawnictwo Uniwersytetu Łódzkiego, Łódź, pp. 415-422.

Fiala, D, Havenith, G, Bröde, P, Kampmann, B \& Jendritzky, G 2012, 'UTCI-Fiala multi-node model of human heat transfer and temperature regulation', International Journal of Biometeorology, vol. 56(3), pp. 429-441.

Fiala, D, Lomas, KJ \& Stohrer, M 2001, 'Computer prediction of human thermoregulatory and temperature responses to a wide range of environmental conditions', International Journal of Biometeorology, vol. 45, pp. 143-159. 
Fortuniak, K2003, Miejska wyspa ciepła. Podstawy energetyczne. Studia eksperymentalne. Modele numeryczne i statystyczne [Urban heat island. Energy basics. Experimental studies. Numerical and statistical models], Wydawnictwo Uniwersytetu Łódzkiego, Łódź.

Havenith, G, Fiala, D, Błazejczyk, K, Richards, M, Bröde, P, Holmér, I, Rintamaki, H, Benshabat, Y \& Jendritzky, G 2012, 'The UTCl-clothing model', International Journal of Biometeorology, vol. 56(3), pp. 461-470.

Instytut Geografii i Przestrzennego Zagospodarowania Polskiej Akademii Nauk 2019, Program BioKlima 2.6. Available from: <http://www.igipz.pan.pl/Bioklima-zgik.html>. [10 May 2019].

Kampmann, B, Bröde, P \& Fiala, D 2012, "Physiological responses to temperature and humidity compared to the assessment by UTCI, WGBT and PHS', International Journal of Biometeorology, vol. 56(3), pp. 505-513.

Kaszewski, BM, Siwek, K \& Gluza, A 2006, 'Cyrkulacyjne uwarunkowania występowania ekstremalnych wartości ochładzania katatermometrycznego w Lublinie (1961-2000)' ['Circulation conditions of occurrence of extreme values of catathermometric cooling in Lublin'] in Funkcjonowanie i monitoring geoekosystemów Polski w warunkach narastającej antropopresji, ed. L Krzysztofiak, Biblioteka Monitoringu Środowiska, Warszawa, pp. 183-192.

Kottek, M., Grieser, J, Beck, C, Rudolf, B \& Rubel, F 2006, 'World Map of the Köppen-Geiger climate classification updated', Meteorologische Zeitschrift, vol. 15, 259-263.

Kovats RS \& Hajat, S 2008, 'Heat stress and public health: a critical review', Annual Review of Public Health, vol. 29, pp. 41-55.

Kozłowska-Szczęsna, T, Błażejczyk, K \& Krawczyk, B 1997, 'Bioklimatologia człowieka. Metody i ich zastosowanie w badaniach bioklimatu Polski' ['Human bioclimatology. Methods and their application in research on the bioclimate of Poland'], Monografie Instytutu Geografii i Przestrzennego Zagospodarowania Polskiej Akademii Nauk, vol. 1.

Kruczko, Z 1962, 'Dni parne w Lublinie' ['Sultry days in Lublin'], Annales UMCS, sec. B, vol. 17(12), pp. 297-306.

Krzyżewska, A, Wereski, S, Demczuk, P 2020, 'Biometeorological conditions during an exceptionally strong heat wave in Poland in August 2015', Weather, vol. 75(6), pp. 183-189.

Kuchcik, M 2017 'Warunki termiczne w Polsce na przełomie XX i XXI wieku i ich wpływ na umieralność' ['Thermal conditions in Poland at the turn of the 20th and 21st centuries and their impact on mortality'], Prace Geograficzne IGiPZ PAN, vol. 263, pp. 1-279.

Kunert, A \& Błażejczyk, K 2011, 'Zróżnicowanie temperatury powietrza w skali lokalnej w różnych typach krajobrazu Polski' ['Variability of air temperature in a local scale in different types of landscape in Poland'], Przegląd Geograficzny, vol. 83(1), pp. 69-90.

Landsberg, HE 1981, The urban climate, Academic Press, New York.

Makhelouf, A 2009 'The effect of green spaces on urban climate and pollution', Iranian Journal of Environmental Health Science \& Engineering, vol. 6(1), pp. 35-40.

Mąkosza, A 2013, 'Bioclimatic conditions of the Lubuskie Voivodeship', Geographia Polonica, vol. 86(1), pp. 37-46.

Mrugała, S 1980, 'Ochładzanie powietrza w Lublinie' ['Cooling air in Lublin'], Folia Societatis Scientiarum Lublinensis, vol. 22, pp. $45-48$.

Mrugała, S 1992, 'Wybrane aspekty zmienności ochładzania katatermometrycznego w Lublinie' ['Selected aspects of the variability of catathermometric cooling in Lublin'], Folia Societatis Scientiarum Lublinensis, vol. 33, pp. 19-23.
Ng, E, Chen, L, Wang, Y \& Yuan, C 2012, 'A study on the cooling effects of greening in a high-density city: An experience from Hong Kong', Building and Environment, vol. 47, pp. 256271.

O'Neill, MS, Carter, R, Kish, JK, Gronlund, CJ, White-Newsome, JL, Manarolla, X, Zanobetti, A \& Schwartz, JD 2009, 'Preventing heat-related morbidity and mortality: new approaches in a changing climate', Maturitas, vol. 64(2), pp. 98-103.

Oliveira, S, Andrade, H \& Vaz, T 2011, 'The cooling effect of green spaces as a contribution to the mitigation of urban heat: A case study in Lisbon', Building and Environment, vol. 46(11), pp. 2186-2194.

Psikuta, A, Fiala, D, Laschewski, G, Jendritzky, G, Richards, M, Błażejczyk, K, Mekjavič, I, Rintamäki, H, Dear, R de \& Havenith, G 2012, "Validation of the Fiala multinode thermophysiological model for UTCI application", International Journal of Biometeorology, vol. 56(3), pp. 443-460.

Salmi, T, Maatta, A, Anttila, P, Ruoho-Airola, T \& Amnell, T 2002, 'Detecting trends of annual values of atmospheric pollutants by the Mann-Kendall test and Sen's slope estimates - the Excel template application MAKESENS', Publications on Air Quality, vol. 31, Finnish Meteorological Institute, Helsinki, Finland.

Scott, D \& Lemieux, C 2010, 'Weather and climate information for tourism', Procedia Environmental Sciences, vol. 1, pp. $146-183$.

Sikora, S 2008, 'Bioklimat Wrocławia' ['Bioclimate of Wrocław'], Rozprawy Naukowe Instytutu Geografii i Rozwoju Regionalnego Uniwersytetu Wrocławskiego, vol. 5.

Skrzypski, J, Papiernik, Ż 2006, Zmiany bioklimatu miast (na przykładzie Łodzi) [Changes in the bioclimate of cities (case study of Łódź)], Polska Akademia Nauk, Oddz. w Łodzi.

Spronken-Smith, RA \& Oke, TR 1998, 'The thermal regime of urban parks in two cities with different summer climates', International Journal of Remote Sensing, vol. 19(1), pp. 2085-2104.

Szymanowski, M 2004, 'Miejska wyspa ciepła we Wrocławiu' ['Urban heat island in Wrocław'], Studia Geograficzne, vol. 77.

Tomczyk, A \& Owczarek, M 2020, 'Occurence of strong and very strong heat sress in Poland and its circulation conditions', Theoretical and Applied Climatology, vol. 139, pp. 893-905.

Urząd Statystyczny w Lublinie [Statistical Office in Lublin] 2019. Available from: <https://lublin.stat.gov.pl>. [6 October 2019].

Wereski, S, Dobek, M \& Wereski, S 2010, 'Częstość występowania poszczególnych odczuć cieplnych w Lublinie i w Lesku na podstawie temperatury odczuwalnej (STI) w latach 1991-2005' ['Frequency of occurrence of particular thermal perceptions in Lublin and in Lesko based on the Standardised Temperature Index (STI) in the years 1991-2005'] in Krajobrazy rekreacyjne - kształtowanie, wykorzystanie, transformacja [Recreational landscapes - shaping, use, transformation], ed. A Richling, Problemy Ekologii Krajobrazu, vol. 27, Polska Asocjacja Ekologii Krajobrazu, Państwowa Szkoła Wyższa im. Papieża Jana Pawła II w Białej Podlaskiej, pp. 371-377.

Zinkiewicz, Z 1969, 'Warunki klimatyczne i bioklimatyczne na obszarze Lubelszczyzny - dla celów gospodarczych' ['Climatic and bioclimatic conditions in the Lublin Region - for economic purposes'], Folia Societatis Scientiarum Lublinensis, vol. 9, pp. 49-53. 